\title{
The Problems of Arab Solidarity and the Impact of Arab Spring on It: Study on the Model of the GCC Security
}

\author{
Salem Toubasi ${ }^{1}$, Ahmad Alzubaidi ${ }^{1}$ \& Mushir Abahra ${ }^{1}$ \\ ${ }^{1}$ Peoples' Friendship University of Russia (RUDN University), Moscow, Russia \\ Correspondence: Ahmad Alzubaidi, Post-graduate student of political sciences (Ph.D), Peoples' Friendship University \\ of Russia (RUDN University), Moscow, ul. Miklukho-Maklaya 6, 117198, Moscow, Russia. E-mail: \\ zbaidy22@gmail.com
}

Received: May 10, 2020

doi:10.5539/jpl.v13n3p160
Accepted: June 19, $2020 \quad$ Online Published: August 20, 2020

URL: https://doi.org/10.5539/jpl.v13n3p160

\begin{abstract}
The author presents a brief study of the Arab solidarity. Furthermore, From the point of view of the author the Arab cooperation is one of the most controversial topics in the Arab world, whereas this idea extends to the first history of the Arab countries, we can also mention the creation of the Gulf Cooperation Council, and then the Maghreb Union of Arab Countries. In this article, the topic of Arab solidarity will be presented, through the views of many thinkers, and based on many analytical researches of Arab public opinion, the view of Arab solidarity and analysis of many ideas put forward for this project. There are new positive ideas possibly can be implemented to achieve the Arab solidarity, which is still a very important project for a wide sector of Arabs, this analytical study will present the case of the Gulf Cooperation Council states as example of positive implementation of Arab solidarity. This article includes the results of Arab public opinion and shed the light on the Arab spring which affected many international and local events. The author asks if Arab solidarity will a real case in the future. This study will investigate these issues and provide the readers with a modern perspective on this topic, furthermore this research approaches this subject from three different areas of discussion: the realism approach, the functionalism approach, and the idealism approach.
\end{abstract}

Keywords: Arab alliances, Arab public opinion, Arab Spring, league of Arab States, Arab integration, military and political security, Arab internal conflicts, Arab unity, Arab solidarity, GCC security, human security

\section{Introduction}

There has been a tremendous radical transformation of the levels of thought and reality and their continuing controversy, which can result in new approaches and cannot remain closed to embryonic perceptions that can claim holiness (Michael, 2005).

Although we cannot ignore the significance of the historical developments taking place in the birth of a new Arabism, cannot imagine that the identity and trends of unity, as expressed by many field studies, unable to give the Arab nation a greater role than it is able to achieve in reality and politics (Ata, 2010, P.4). Ata (2010) also found that the existence of a nation does not guarantee its political unification, and the common factors that countries have achieved through a transformed historical process are not always sufficient to be a nation, it is also not the only requirement for its unification, these centrality factors were insufficient to ensure Arab political unity in the past.

Unity forces and fragmentation forces are also dynamics that work together in a dialectical relationship, according to its logic of operation that cannot consider unity as an inevitable consequence of it or vice versa or, or consider that it can occur spontaneously (Burhan, 2013, P.93). Burhan (2013) also found that the experience that has emerged have shown that the importance of social integration is essential and that the countries must not ignore what happening in every Arab country, which is more important than the reliance on the common factors among Arabs

This development is essential and should not be overlooked, especially in light of the recent developments at the Arab level. Therefore, it is no longer acceptable to call for unity only on the basis that unity has been achieved in the past or the possibility of imitating the experience of other countries that have achieved their political unity (Mahmoud, 2017, P. 45). Mahmoud (2017) Also found the Arab unity and other forms of levels of integration or 
political cooperation are today a desirable future state in the Arab world, the results and indicators of field studies of Arab public opinion trends strongly expressed these results.

The Arabs have clearly expressed their views that Arab unity or other levels of integration and cooperation are more for the Arabs of today than the emotional reproduction of a glorious and imagined Arab history, which is not merely the embodiment of an Arab identity or the unification of a fragmented nation. based on different levels, however it is also the same Arab people who have decided to rise against the authority which has been entrenched behind the strength and violence of its security apparatus and protected from cross-border Arab influences by the legitimacy of Traditional nation state (Yusuf, 1988).

Therefore, the Arab people today are more prepared and qualified by the developments. Many indicators have shown - that the Arab peoples today do not consider full political unification or integration unity as the inevitable result of common factors. The Arab peoples of today are no longer content with the previous beliefs, as expressed by the Baath ideology, for example, in the eternal nation with the sacred message (Yousef, 2014, P.47).

\section{Study Methodology}

In this study, the researchers used three approaches to study the problem of research from multiple angles. In the first section of the research, a focus was placed on the Functionalism school in the study of Arab solidarity, the importance of achieving solidarity to achieve the functions of this unit, and since the idea of solidarity is a perception of a higher model from the state, the researcher Use the idealism also curriculum as well. In the second section of the research, the focus was on the realistic approach in order to compare the ideal idea of unity with reality, where the Gulf Cooperation Council was chosen as a realistic case of Arab study.

The researcher used these approaches for reasons related to the nature of Arab societies and countries, as he notes how there is a difference in desires and aspirations between the governments of Arab countries and their peoples. The aspirations of the Arab peoples are more idealistic, while the governments of the Arab countries have more faith in reality. The Functionalism approach also tries to balance between realism and idealism.

\section{Arab Unity in the Idealism and Functionalism}

Unity in the new Arab model does not seem merely an expression of identity or common factors, but rather a necessity imposed by the common interest that is linked to what the Arab Renaissance project describes as the challenges of the present and the future in the fields of economic, scientific and cultural development, national security and the necessities of survival. Development and raising the standard of living of the Arab citizen, and to protect the homeland including the people (Saad, 2013).

Saad (2013) also found therefore, the realization of a form of Arab unification or integration becomes linked to the reality of the traditional Arab state, its mean that whenever Traditional nation state makes progress in unifying its national entity, in achieving economic and scientific development, in the equitable distribution of wealth, in building the foundations of a democratic life, in maintaining its national security and developing its capabilities, these will be the foundations for reaching the Arab Unity Project.

The Arab Unity Project has the necessary infrastructure, if growth is achieved in various sectors. It is related to this statement that whenever Traditional nation state succeeds in achieving internal social integration among the various constituent groups of the entity, the more open the way to achieve national integration and after that the Arab unity

Saad (2013) also found it seems logical that when it comes to the appropriate form of approach to the goal, the Arab Renaissance project expressing the content of the new Arab model determines that the formula of integration is not the appropriate way for the Arab Renaissance project. The formula of the Confederal or Federal state is appropriate. This is the preferred formula today because it can express compromise and can lead to the establishment of joint institutions that do not abolish the existence of Traditional nation state authority and its institutions. The new faith in the functional approach expressing the logic of its work at multiple levels to make the success of the federal gradual It starts between only a limited number or two countries, and the rise of its gains, encouraging the accession of other countries to it.

The new Arab model (the Arab Renaissance project) is consistent with the results of several field studies by paying attention to what has been neglected in the past concerning the goal of achieving Arab unity. Therefore, the Arab renaissance project confirms that "achieving Arab unity is a long-term project that is being accomplished gradually: step by step and by accumulation. It is indisputable that this evolution of the approach, as expressed in the contributions of the new model, makes Arab unity a possibility for the dynamics of the transformed reality rather than just the desires. 
The Arab world faces the challenge of many societal problems, and the Traditional Arabic state have been devoted for many important levels, this is due to the unprecedented intensity Arab-Arab communications in recent decades, this work to Improve intensity communications and its undoubtedly works to make the idea of Arabism present in the minds and realities (Ghassan, 2011, P.101).

Moreover, there are apparent problems in the fields of politics, economy and development, perhaps the most visible form of their presence, which is reflected in the feelings and healthy common sense expressed by Arab citizens of these problems. Its the challenges and dangers that threaten the Arab communities and the Arab States and the almost complete agreement in identifying the sources of the threat between them.

To the extent that these developments call for optimism, they should also stimulate further intellectual and scientific efforts to test the ability of Arab thought to respond to the needs of the modern Arab citizen. This and its translation in joint Arab researches, studies and projects will strengthen the strength of the positive trends revealed by the various surveys and help to identify the appropriate means to promote these rational and realistic elements in the thought and practice of the Arab peoples in the twenty-first century.

Also, this civilization, with its impact that it holds in its essence, is still present today in the rest of the world because of the extension of Islam gives an important dimension to the Arab culture, since its culture is related to an inseparable connection with Islam, because the spread of Islam, including its connection to the Arabic language in various parts of the earth And for example, Central Asia, this gives importance to Arab civilization, giving it the necessity to be a single unit, as its culture is spread outside its geographical borders (Kozmenko, Logacheva, Toktamysov, Belanovaskaya, 2020, P.452).

\section{The Gulf Cooperation Council in Realism}

Article 4 of the Basic Law of the Gulf Cooperation Council states that the goal of the Gulf Cooperation Council is established" 1- Achieving coherence, complementarity and interdependence among Member States in all fields All the way to her unit, 2 deepening and strengthening the ties, connections and aspects of cooperation existing between their peoples in various fields....". Nevertheless, the aforementioned Cooperation Council statute signed by the leaders of the six countries on May 25, 1981 - did not refer to the security dimension, while a note of the proposals submitted by the member states to form the council reveal the security motivation's control over the idea of its establishment, the Saudi and Omani proposals, the first called for the establishment of a Gulf organization aimed at unifying the arms sources of the Gulf states, and establishing broad cooperation between the internal security forces in the countries concerned, while the proposal called The Omani initiative to establish a joint naval force to protect and defend the Strait of Hormuz as a lifeline in the region. As for the Bahraini initiative, it was the result of the awareness of the late Emir of Bahrain, Sheikh Isa bin Salman Al Khalifa, of the need to confront regional threats against the Gulf states.

It is noticed in the Gulf region as in the rest of the Middle East, that the concept of security that controls government studies and policies is security in its political sense more than any other dimension of national security, as the national security of states consists of Military security, political security, economical security and social and cultural security (Adel, 2016, P. 75). Adel (2016) also found there is states differ in their interest in the dimensions of national security previous mentioned. Security in its military sense and political security means preserving the ruling regime in the state and military security focuses on preserving the state with all its institutions from any material danger coming from inside or outside

There are many security issues that the six Arab countries have found heading for the establishment of the council, the most important of which are the 1979 Iranian Islamic Revolution, the conflict in Afghanistan, the outbreak of the Iraq-Iran war and differing positions on the Arab-Israeli conflict, Egyptian in particular.

In fact, at the time of the establishment of the traditional Arab states, the Arab people did not have an independent opinion of the governments, until the governments became an isolated class from the people after they were a semi-elected representative of the peoples. This separation causes the Arab spring.

While the term human security is a newly emerging, it is the basis for the establishment of a strong state entity, Western countries for example are concerned with human security as well as political and military security. Protect citizens, this is the function of the modern state, and consequently, it was assumed that human security leads directly to serve the rights of citizens in the state because it is related to various aspects of human rights (Khawla, 2012, P. 2). Khawla (2012) also found that while military security guarantees only the right to life and the preservation of the integrity of the body, human security includes aspects related to human life more than the last two things

From another point of view, human security lawsuits opened the way to popular protests since 2011 in all Arab 
countries and these demonstrations threatened to topple the regimes of governance in the Gulf Cooperation Council (Al-Otaibi, 2019). Al-Otaibi (2019) also found as the idea of human security is related to many issues, which makes it a dangerous idea, because it may be reflected in the weakening of the margin of human security itself, and give an opposite effect, and the most important example is that the Kingdom of Saudi Arabia supported the counterrevolution, with a valid justification which is protection from danger The Iranian, who began to penetrate the Arab region, taking advantage of the peoples 'attempt to change the margin of human security

It is important to note that a high per capita share does not mean that human security is achieved. The Gulf Cooperation Council countries are among the most countries in the world where the per capita share is considered high, and yet these countries have many observations in violation of human rights issues.

In defiance of the rest of the countries in the Gulf Cooperation Council and in particular (Saudi Arabia, the United Arab Emirates and Bahrain), the Traditional nation state has maintained its excellent relations with Tehran, even though this bothers Riyadh, Abu Dhabi and Manama, which already has bad relations with Iran. The Traditional nation state has sought to conclude several agreements with Tehran, including security and military agreements, and has also been involved with the Yemeni government and the Houthi rebels in their talks, despite the Houthis' threat to Saudi and Emirati security (Gregory, 2014, P.1).

The State of Qatar wanted to play an influential role in foreign policy that exceeds its natural size after the political change that occurred with Sheikh Hamad's coming to power in 1995, not only at the level of the Arab Gulf region, but also wanted to transform from a country of limited power to a country with influence and interests and benefits exceeding The Cooperation Council for the Arab States of the Gulf is dependent on the return on the oil and gas wealth, which has witnessed a tremendous increase, which has enabled it to adopt the concept of soft power in its external dealings and to compete with the large Arab regional leaderships of the Arab and Islamic world through Al Jazeera satellite channel, with use the money to support the Arabian revolutions, and the groups that are considered terrorist organizations, from the standpoint of political systems ( Arafat, 2014, P.20).

And Qatar's support for the Arab Spring revolutions does not mean that Qatar supports the Arabs and the unity of the Arabs and the rest of the Gulf Cooperation Council states against the unity of the Arabs, but these countries, headed by Saudi Arabia, focus in their policy on supporting the unity of the Arab countries through meetings and agreements at the level of state policies, in contrast to Qatar, which holds that unity must be derived from peoples. But Qatar does not focus on itself on this issue (Ahmed, Jawad, \& Abdul-Fattah, 2015, P.81).

The difference between the Kingdom of Saudi Arabia and Qatar over the political approach in achieving Arab and Islamic rapprochement led to the emergence of a crisis of relations in the Gulf Cooperation Council. Saudi Arabia, Bahrain and the UAE were boycotted Qatar on the basis of it, which threatens the existence of the Gulf Cooperation Council. And this crisis started in the year 2014 by withdrawing the ambassadors from Qatar, and then escalating again in the year 2017 by blockading Qatar and mobilizing against it from many Arab countries (Rory, Harry, 2019, P. 1).

This conflict is a struggle between democracy and the traditional state. All the countries of the Gulf Cooperation Council follow a monarchy in the rule of the state. Although the Qatari regime is undemocratic, it tries to spread democracies, this paradox comes from pragmatic policies. The Qatari political system stile remained a beneficiary even though it supports democracies by improving its image in front of peoples in other countries, and this is reflected in the Qatari people who will see his government is democratic, thus democracy emerges as a kind of convincing people that the state is a democracy without turning to democratic systems of governance the state (Thomas, 2009, P. 104).

Qatar supports political Islam movements, as political Islam movements are the democratic choice for the Arab peoples, while the others see this as a threat to Arab countries and support for terrorism and extremism. Is the arrival of Islamic groups to power through democracy is political Islam, and is it in the interest of Arab peoples and their right or is it a danger to them and must be prevented from it (Abdullah Baabood, 2019, P.28).

In 1970 Hussein Mahdawi introduced the term rentier state, a term that refers to the country that spends on its citizens from what it sells of its resources abroad, and these countries do not take taxes but rather spend on their citizens, and this according to theory reduces the desire of members of society to represent In governments, the nature of tribal societies makes the generous person that distributes wealth, who rule of the political system (Courtney, 2018, P.20).

It makes the division of oil wealth a smooth thing, it seems. It is among the principles of the Bedouin tribes that generosity and courage is what makes a person a leader over a people, and therefore the continuation of the resources returning from the sale of oil is a fundamental reason for the continuation of the regimes as they are, and 
therefore we will find Political Islam movements like the Muslim Brotherhood in the countries of the Gulf Cooperation Council are less than in the rest of the Middle East, on the political level, however, it is present on the social level in the GCC.

Here a distinction must be made between two things, first the use of political Islam, that is, what governments practice in the name of religion to achieve goals in the service of politics, as this is considered use of political Islam, whether it is a country with a Muslim majority or not. The second is the real political Islam, it's the desire of the political authority to implement Islamic law in all sections of life from the high of the authority.

The question is Saudi Arabia within any category? Sometimes Saudi Arabia use political Islam while at other times Saudi Arabia is the authority which do the role of political Islam itself. Today, since the year 2017, with the policy of Saudi Crown Prince Mohammed bin Salman, it has been moving away from every link between politics and Islam as much as possible.

Since the Islamic slogans have a great ability today to move the Arab peoples, Arab governments are trying to defer Islam from political life as much as possible, in order to achieve the political and military security that these countries see is the most important type of security. Also, the problem of terrorism has become a real threat to the security of these countries.

Although, according to the logic of size, it is assumed that the smaller country follows the larger country to achieve a greater degree of union, the State of Qatar constitutes an area of half a percent with respect to the area of the Kingdom of Saudi Arabia, and yet it takes decisions with full independence from the Kingdom of Saudi Arabia.

\section{Conclusions}

Throughout this article, several issues were discussed and resulted in several important points that must be mentioned in a whole; first of all, there is much hope in the future for more changes at the level of Arab rapprochement than in the past, with a very high separation between the Arab peoples and Arab governments. Moreover, the desires and concepts of these peoples are different from the wishes of the governments and their perceptions towards the rapprochement of Arab unity. Then The security in the view of Arab governments is to preserve the existing security conditions. In contrast, Arab people see that a higher degree of human security must be achieved, otherwise extremist movements will try to wrest power as a result of marginalizing many groups of society at the economic and political levels. The conflict that exists today is a conflict of interest. First, the interests of traditional conservative forces are represented in the regimes of monarchy and the interests that surround them. Second, the interests of marginalized groups.

Another critical point that we notice in the article is that the Royal regimes can eliminate this conflict by creating a perception of political representation in the minds of peoples by raising citizens' satisfaction with the government, without actually changing the political system.

With the deterioration of the ability of governments to control the communications of the Arab peoples and their interactions with the increases in the capabilities of communication and influence, Arab unity has become a matter of imperative necessity. However, it remains subject to the conditions that may arise. Moreover, From the text of the legislative statute of the Gulf Cooperation Council, we find that this council has the capabilities to achieve a federal state will then expand to include other Arab countries, which must overcome the problems resulting from the dispute between the policies of political systems and focus on the interdependence of peoples through the establishment of unified parliaments as the European Union, and that in order to unify the legislation.

The last issue of these results is that the Arabs must transcend political Islam and political tyranny in order to stop at a stage during which people understand and create larger entities able to integrate more elements.

\section{References}

Adel, A. T. (2016). National Security and Human Security a Study in Concepts. Journal of Political Science: College of Political Science, Baghdad University, 75-102. Retrieved from https://www.iasj.net/iasj?func=fulltext\&aId=120552

Ahmed, A. B., Jawad, J. H., \& Abdul-Fattah, A. R. (2015). The prospects for Saudi foreign policy during the reign of King Salman bin Abdulaziz. Jordan (Amman): Middle East Studies Center.

Al-Otaibi, A. S. (2019). The impact of Arab Revolution on the security of the Arabian Gulf: The Yemeni Revolution as a model. Review of Economics and Political Science, 5(2), 136-148. https://doi.org/10.1108/REPS-02-2019-0022

Arab Center for Research and Policy Studies. (2018). Arab Public Opinion Measurement Project (Issue brief no. 1). Doha: Arab Center for Research and Policy Studies. 
Arafat, A. J. (2014). The Qatari position on Arab revolutions and its effect on the transformations of Qatari foreign policy. Al-Mustansiriya Center for Arab and International Studies, 48, 30-59. Retrieved from https://www.iasj.net/iasj?func=fulltext\&aId $=96387$

Ata, H. (2010). An Arab Awakening Tied to Arab Union's Formation. Canada (Victoria): Trafford Publishing. Retrieved from https://play.google.com/books/reader?id=QRddAAAAQBAJ\&hl=ar\&pg=GBS.PT4

Baabood, A. (2019). Davidson, Divided Gulf, The UAE, Qatar, and the Question of Political Islam. Retrieved from https://link.springer.com/chapter/10.1007/978-981-13-6314-6_5

Courtney, C. F. (2018). Rentier Islamism: The Influence of the Muslim Brotherhood in Gulf Monarchies. United States of America: Oxford University Press.

Ghalioun, B. G. (2014). The Arab Plight: The State Against the Nation. Qatar: Arab Center for Research and Policy Studies. Retrieved from https://play.google.com/books/reader?id=rb1mDwAAQBAJ\&hl=ar\&pg=GBS.PT2

Ghassan, G. S. (2011). Towards a New Arab Social Contract: Research on Constitutional Legitimacy. Beirut: Center for Arab Unity Studies.

Gregory, G. F. (2014). Beyond Sectarianism: The New Middle East Cold War. Doha: Brookings Doha Center. Retrieved from https://www.brookings.edu/wp-content/uploads/2016/06/English-PDF-1.pdf

Khawla, K. M. (2012). Human Security and Dimensions in Public International Law. University Journal for Economic and Legal Sciences, 28, 2-87. Retrieved from http://aems.edu.sd/wpcontent/uploads/2019/03/\%D8\%A7\%D9\%84\%D8\%A7\%D9\%85\%D9\%86-\%D9\%84\%D8\%A7\%D9\%86\% D8\%B3\%D8\%A7\%D9\%86\%D9\%8A-\%D9\%88\%D8\%A7\%D8\%A8\%D8\%B9\%D8\%A7\%D8\%AF\%D9\% 87-\%D8\%A7\%D9\%84\%D9\%82\%D8\%A7\%D9\%86\%D9\%88\%D9\%86\%D9\%8A\%D8\%A9.pdf

Kozmenko, K. V., Logacheva, L. N., Toktamysov, T. S., \& Belanovaskaya, B. Y. (2020). The historical role of Islam in the public life of the Central Asian region of the CIS in the XX - XXI centuries. Revista Amazonia Investiga, $9(25), \quad 452-460 . \quad$ Retrieved from https://amazoniainvestiga.info/index.php/amazonia/article/view/1094/1002.

Mahmoud, M. I. (2017). The Arab world and alternative integration projects. Beirut: Center for Arab Unity Studies. 45-139.

Michael, M. J. B. (2005). The Evolution of Thought: Evolutionary Origins of Great Ape Intelligence. Apes, Monkeys, Children, and the Growth of Mind. International Journal of Primatology, 26, 1203-1207. Retrieved from https://link.springer.com/article/10.1007/s10764-005-6469-x

Rory Miller, R. M., \& Harry Verhoeven, H. V. (2019). Overcoming smallness: Qatar, the United Arab Emirates and strategic realignment in the Gulf. International Politics, 57, 1-20. Retrieved from https://link.springer.com/article/10.1057/s41311-019-00180-0

Saad, S. H. (2013). The Arab Renaissance Project: Call for the Future. Beirut: Center for Arab Unity Studies.

Thomas, T. P. (2009). Democracy, autocracy and the likelihood of international. Economics of Governance, 10, 104-245. Retrieved from https://link.springer.com/article/10.1007/s10101-008-0055-6

Yousef, Y. S. (2014). Trends of Arab Public Opinion in Arab Unity. Beirut: Center for Unity Studies.

Yusuf, Y. Q. (1988). Arab Unity Projects documents (Brief No. 3191-7891). Beirut: Center for Arab Unity Studies.

\section{Copyrights}

Copyright for this article is retained by the author(s), with first publication rights granted to the journal.

This is an open-access article distributed under the terms and conditions of the Creative Commons Attribution license (http://creativecommons.org/licenses/by/4.0/). 